\title{
Temporal changes in HCV genotype distribution in three different high risk populations in San Francisco, California
}

\author{
Paulo Telles Dias ${ }^{1,2}$, Judith A Hahn ${ }^{3}$, Eric Delwart ${ }^{4}$, Brian R Edlin ${ }^{5}$, Jeff Martin ${ }^{5,5}$, Paula Lum ${ }^{7}$, Jennifer Evans ${ }^{2}$,
} Alex Kral ${ }^{8}$, Steve Deeks ${ }^{7}$, Michael P Busch ${ }^{4,9}$ and Kimberly Page ${ }^{2,6^{*}}$

\begin{abstract}
Background: Hepatitis C virus (HCV) genotype (GT) has become an important measure in the diagnosis and monitoring of HCV infection treatment. In the United States (U.S.) HCV GT 1 is reported as the most common infecting GT among chronically infected patients. In Europe, however, recent studies have suggested that the epidemiology of HCV GTs is changing.
\end{abstract}

Methods: We assessed HCV GT distribution in 460 patients from three HCV-infected high risk populations in San Francisco, and examined patterns by birth cohort to assess temporal trends. Multiple logistic regression was used to assess factors independently associated with GT 1 infection compared to other GTs (2, 3, and 4).

Results: Overall, GT 1 was predominant (72.4\%), however younger injection drug users (IDU) had a lower proportion of GT 1 infections (54.7\%) compared to older IDU and HIV-infected patients (80.5\% and 76.6\%, respectively). Analysis by birth cohort showed increasing proportions of non-GT 1 infections associated with year of birth: birth before 1970 was independently associated with higher adjusted odds of GT 1: AOR 2.03 (95\% Cl: 1.23, 3.34). African-Americans as compared to whites also had higher adjusted odds of GT 1 infection (AOR: 3.37; $95 \%$ Cl: $1.89,5.99)$.

Conclusions: Although, HCV GT 1 remains the most prevalent GT, especially among older groups, changes in GT distribution could have significant implications for how HCV might be controlled on a population level and treated on an individual level.

Keywords: hepatitis C virus, HCV, GT, injection drug use, HIV, birth cohort, African-American

\section{Background}

Hepatitis C virus (HCV), first identified in 1990, is a single strand RNA virus in the family Flaviviridae. It is prone to high rates of genetic mutation, resulting in evolution to divergent forms and six major genotypes [1]. Each genotype (GT) is further divided into subtypes, based on genetic sequence variability. There are notable clinical differences in responsiveness to interferon-based therapy for treatment of chronic infection by GT, with GTs 1 and 4 being less responsive and requiring longer

\footnotetext{
* Correspondence: kpage@psg.ucsf.edu

${ }^{2}$ Department of Epidemiology and Biostatistics, Division of Preventive Medicine and Public Health, Box 1224, 50 Beale Street 1200 University of California San Francisco, San Francisco, CA USA Full list of author information is available at the end of the article
}

exposure time to treatment than types 2 and 3 [2-5]. GT has been associated with different patterns in $\mathrm{HCV}$ viremia during interferon treatment [6], and antiviral resistance $[7,8]$. Although some clinical conditions have been noted to differ by HCV GT, including insulin resistance [9], HIV and HIV disease progression [10], little is known regarding how different HCV GTs differ in virulence or pathogenicity [11]. African Americans infected with GT 1 are significantly less likely to respond to HCV treatment than Asian and Caucasian patients with GT $1[12,13]$. Patients infected with GT 1 who carry a genetic variant allele near IL28B gene are more likely to respond to combination therapy (pegylated interferonalpha-2a or $-2 \mathrm{~b}$ and ribavirin) [14] and clear spontaneously [15]. As this polymorphism varies by race [14],
C Biomed Central 
it partially explains differences in these outcomes. Finally, GT heterogeneity may hinder the development of a vaccine [16].

In the U.S. HCV GT 1 has been the most common infecting subtype; over $70 \%$ of patients with chronic infection are GT 1 [17-19]. In Europe, however, recent studies have reported more variation in the extent and diversity of HCV GTs, and have shown associations between HCV GT and risk exposure, age, and clinical group [20-24]. In the U.S., race/ethnicity have been found to be independently associated with GT in the NHANES general population sample [19] and in other samples [18], but none have examined temporal changes in circulating infecting GTs.

The objective of this study was to examine the distribution of prevalent HCV GTs in various high risk populations in San Francisco by birth cohort and other demographic factors.

\section{Methods}

We examined data from three prospective cohort studies in San Francisco, California, U.S. In total, 460 chronically HCV infected persons were included from the following studies, all with IDU exposure: 1) The "Urban Health Study" (UHS), a prospective serial crosssectional study of IDU recruited from San Francisco neighborhoods with high prevalence of IDU[25]; 2) The UFO Study, a prospective cohort study on the incidence of HCV infection in young ( $<30$ years) street-recruited IDU[26]. 3) The "Study of the Consequences of the Protease Inhibitor Era" (SCOPE) Study, a prospective, observational study of HIV positive patients[27]. Subjects included in this study were recruited over varying intervals during a twenty-year time period between 1987 and 2007 (Table 1). HCV GT was assessed in the participants with incident HCV infection in the UFO Study and the UHS using stored sera specimens from blood samples taken at the visit of first HCV detection (antiHCV or HCV RNA). In the SCOPE study HCV GT was determined from stored samples of prevalent infection obtained at first or second study visit (if not available from the first study visit).

In all studies anti-HCV and $\mathrm{HCV}$ viremia were assessing using Ortho EIA 3.0, with confirmation by RIBA 3.0, Chiron, Corp, and a discriminatory HCV transcription-mediated amplification (dHCV TMA) assay component of the Procleix HIV-1/HCV assay (Novartis Diagnostics, Emeryville, CA, USA), respectively. HCV GT was determined by the LiPA Line Probe Assay (Bayer Diagnostics, Tarrytown, NY, USA). Indeterminate GTs and co-infected cases were not included in the final analysis of the study.

We assessed differences between the study groups and between GT 1 versus other GTs with respect to sociodemographic and clinical variables using standard methods. Differences in proportions were compared using Pearson Chi-Square tests. Differences in variables with continuous data were assessed by comparing medians and distributions using the Kruskal-Wallis test. We examined HCV GT distribution by birth cohort to assess trends by 10-year birth intervals using the Mantel-Haenszel Chi-Square test for trend. Multiple logistic regression was used to assess factors independently associated with GT 1 infection compared to other GTs (2, 3, and 4); adjusted odds ratios (AOR) and 95\% Confidence Intervals (CI) were calculated. Models were constructed in an iterative backwards stepwise manner. All variables with a $\mathrm{p}$-value $<=0.05$ at the bivariate level were entered into the model and removed one by one. Variables with a p-value of $<=0.10$ were retained in the final model. All analyses were conducted using SPSS for Windows statistical software package (version 13).

All of the research from participating studies in this project was conducted under protocols reviewed and approved by the University of California San Francisco Human Subjects Research Committee, and conformed to the Helsinki Declaration and local regulations. All study subjects gave informed consent for participation.

\section{Results}

Of the 460 persons included, 202 (43.9\%) were from the UHS; 128 (27.8\%) from UFO; and 130 (28.3\%) from the SCOPE studies. Table 1 shows participant characteristics by study. There were significant differences in age, race/ ethnicity and educational background between the three groups, and males comprised the majority (69.4\%) in all. GT 1 was predominant (72.4\%) overall, however between groups the distribution of GTs was significantly different. Young IDU (the UFO Study) had the lowest proportion of GT 1 infections (54.7\%) compared to older IDU (UHS) and HIV-infected patients (SCOPE) who had $80.5 \%$ and $76.6 \%$, respectively. Analysis by birth cohort also showed significant differences (see Figure 1). The more recent birth cohorts had increasing proportions of non-GT 1 infections compared to less recent birth cohorts, and young IDU specifically had more GT 3 infections compared to others (Table 1 ). Table 2 shows the bivariate and multivariate results of variables associated with GT 1 infection compared to GTs 2, 3, and 4 (non-GT 1) infection. Factors independently associated with prevalent infection with HCV GT 1 included birth cohort and race/ ethnicity. Patients born before 1970 had higher adjusted odds of GT 1 infection compared to those born more recently: AOR 2.03 (95\% CI: 1.23, 3.34); age and study group were not included in the final model due to colinearity with birth cohort. African-Americans compared to Caucasian patients were more likely to have GT 1: AOR 3.37 (95\% CI: 1.89, 5.99). 
Table 1 Selected characteristics of participants in three studies of HCV infection in San Francisco $(N=460)$

\begin{tabular}{|c|c|c|c|c|}
\hline Variables & UHS & UFO & SCOPE & Total all studies \\
\hline Total N & 202 & 128 & 130 & 460 \\
\hline \multicolumn{5}{|l|}{ Gender N(\%) } \\
\hline Male & $145(72.5 \%)$ & $88(68.8 \%)$ & 85 (65.4\%) & $318(69.4 \%)$ \\
\hline Female & $55(27.5 \%)$ & $40(31.2 \%)$ & $45(34.6 \%)$ & $140(30.6 \%)$ \\
\hline \multicolumn{5}{|l|}{ Age (in years)\# } \\
\hline Median & 47.0 & 22.3 & 45.0 & 43.0 \\
\hline IQR & $42.3-50.0$ & $19.9-25.0$ & $40.8-49.0$ & $28.0-48.0$ \\
\hline Years of recruitment & 1987-1998 & 2000-2007 & 2000-2007 & 1987-2007 \\
\hline HCV Genotypes* & & & 95 (77.9\%) & $326(72.4 \%)$ \\
\hline Type 1 & $161(80.5 \%)$ & $70(54.7 \%)$ & $10(8.2 \%)$ & $50(11.1 \%)$ \\
\hline Type 2 & $22(11.0 \%)$ & $18(14.1 \%)$ & $15(12.3 \%)$ & 69 (15.3\%) \\
\hline Type 3 & $15(7.5 \%)$ & $39(30.5 \%)$ & $2(1.6 \%)$ & $5(11.1 \%)$ \\
\hline \multirow[t]{2}{*}{ Type 4} & $2(1.0 \%)$ & $1(0.8 \%)$ & $122(100 \%)$ & $\#^{* * *}$ \\
\hline & $\#^{*}$ & & $\#^{* *}$ & \\
\hline \multicolumn{5}{|l|}{ HCV Genotypes* } \\
\hline 1 & $15(7.4 \%)$ & $32(25.0 \%)$ & $62(47.7 \%)$ & $110(23.9 \%)$ \\
\hline $1 a$ & $76(37.6 \%)$ & $26(20.3 \%)$ & $3(2.3 \%)$ & $105(22.8 \%)$ \\
\hline $1 \mathrm{a} / 1 \mathrm{~b}$ & $5(2.5 \%)$ & $1(0.8 \%)$ & $4(3.1 \%)$ & $10(2.2 \%)$ \\
\hline $1 b$ & $65(32.2 \%)$ & $11(8.6 \%)$ & $26(20.0 \%)$ & $101(22.0 \%)$ \\
\hline $1 / 2$ & $1(0.5 \%)$ & $0(0.0 \%)$ & $0(0.0 \%)$ & $1(0.2 \%)$ \\
\hline 2 & $1(5.0 \%)$ & $5(3.9 \%)$ & $0(0 \%)$ & $5(1.1 \%)$ \\
\hline $2 a$ & $0(0.0 \%)$ & $1(0.8 \%)$ & $0(0.0 \%)$ & $1(0.2 \%)$ \\
\hline $2 \mathrm{a} / 2 \mathrm{c}$ & $4(2.0 \%)$ & $6(4.7 \%)$ & $2(1.5 \%)$ & $12(2.6 \%)$ \\
\hline $2 b$ & 17 (8.4\%) & $6(4.7 \%)$ & $3(2.3 \%)$ & $26(5.7 \%)$ \\
\hline $2 b / 3 a$ & $1(0.5 \%)$ & $0(0.0 \%)$ & $0(0.0 \%)$ & $1(0.2 \%)$ \\
\hline $3 a$ & $15(7.4 \%)$ & $39(30.5 \%)$ & 15 (11.5\%) & 69 (15.0\%) \\
\hline 4 & $1(0.5 \%)$ & $0(0.0 \%)$ & $1(0.8 \%)$ & $4(0.4 \%)$ \\
\hline $4 c / 4 d$ & $1(0.5 \%)$ & $1(0.8 \%)$ & $1(0.8 \%)$ & $3(0.7 \%)$ \\
\hline Undetermined & $0(0.0 \%)$ & $0(0.0 \%)$ & $8(6.2 \%)$ & $8(1.7 \%)^{* *}$ \\
\hline \multicolumn{5}{|l|}{ Ethnicity } \\
\hline Caucasian & $55(27.5 \%)$ & 97 (75.8\%) & 54 (41.5\%) & $205(44.8 \%)$ \\
\hline African Amer. & $124(62.0 \%)$ & $2(1.6 \%)$ & $54(41.5 \%)$ & $180(39.3 \%)$ \\
\hline Latino & $10(5.0 \%)$ & 7 (5.5\%) & 9 (6.9\%) & $26(5.7 \%)$ \\
\hline Asian & $1(0.5 \%)$ & $1(0.8 \%)$ & $3(2.3 \%)$ & $5(1.1 \%)$ \\
\hline Other & $10(5.0 \%)$ & $21(16.4 \%)$ & $10(7.7 \%)$ & $42(9.2 \%)^{* *}$ \\
\hline \multicolumn{5}{|l|}{ Education (1)ף } \\
\hline$<$ High School & $56(28.0 \%)$ & $67(52.8 \%)$ & $34(26.2 \%)$ & $157(34.4 \%)$ \\
\hline$>=$ High school & $144(72.0 \%)$ & 60 (47.2\%) & 96 (73.8\%) & $300(65.6 \%)^{* *}$ \\
\hline
\end{tabular}

* Co-infected cases not included.

** Statistically significant difference $(p<0.05)$

\# Age at the time of the interview

I Some cells do not conform to the total sample size totals due to missing data

\#* 2 people co-infected with different genotypes were not included

$\#^{* *} 8$ people with undetermined genotypes were not included

$\#^{* * *} 10$ people not included due to undetermined genotypes or to co-infection with different genotypes

\section{Discussion}

These results suggest that in San Francisco, within the ongoing $\mathrm{HCV}$ epidemic, the epidemiology of infecting $\mathrm{HCV}$ viruses has changed over time. Among younger IDU, who are also more likely to have more recent infection, non-GT 1 is increasingly prevalent. Historically, few studies have been published describing GTs in San Francisco patients. In 1999, Gish et al, [28] described GTs (using restriction fragment length polymorphism analysis) in 186 patients with chronic HCV 


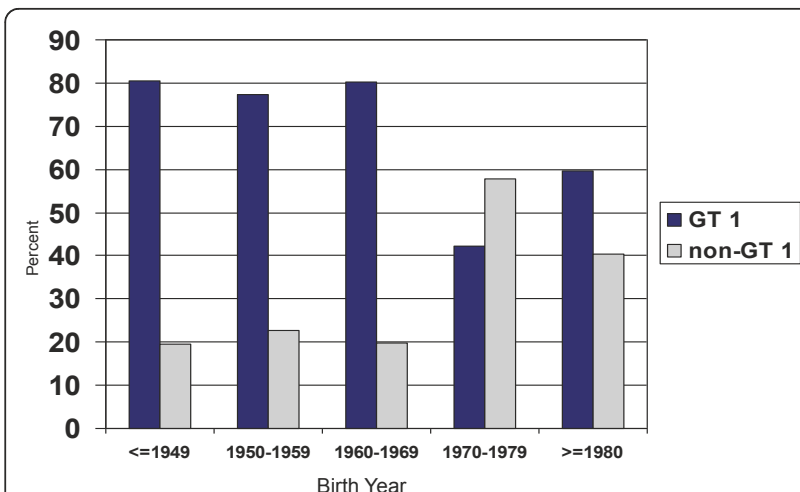

Figure 1 Distribution of HCV genotypes 1 and non-1 among three high risk populations in San Francisco by birth cohort (decade)

(the majority presumptively IDU); $76 \%$ were type 1 (1a, $41 \%$; $1 \mathrm{~b}, 35 \%), 13 \%$ were type 2 (2a, $3 \% ; 2 \mathrm{~b}, 10 \%)$ and $11 \%$ were type $3 \mathrm{a}$. In that sample, HCV GT was not associated with age, gender, ethnic origin, or presumptive mode of transmission. In two small groups $(n=8$ each) of chronically HCV infected, active and former IDU recruited from two urban San Francisco Hospitals, $75 \%$ of active IDU (median age 47 years) and all of the former IDU (median age 49) were type 1. As patients in these studies were more heterogeneous with respect to routes of exposure, and were likely to have been infected some years before clinical assessment, these data are consistent with the suggestion that type 1 GTs were more prevalent in San Francisco IDU in the 1990's.

In Europe, Simmonds et al [29] showed an association between HCV GT and age, and attributed it primarily to risk exposure differences. In Germany, Schroter et al [24] also showed increases in GTs 3a in younger groups, including IDU and non-IDU, leading these authors to hypothesize that the introduction of new subtypes in a high risk group may rapidly impact lower risk groups. Others have shown differences in HCV GT distribution by route of exposure, with GT 3a associated with injection exposures, and GT $1 \mathrm{~b}$ associated with acquisition through blood transfusion [21,22,30,31]. In a multicentre study of HCV infection in $183 \mathrm{HIV}$-infected IDU sampled between 1984 and 2001, Van Asten et al [32], using phylogenetic analyses, found that subtypes $3 \mathrm{a}$ and 1a were most prevalent (38.3\%, and $36 \%$, respectively) and extensively dispersed throughout the countries.

The relative differences in HCV GT seen in these San Francisco patients may be due to various factors, including temporal changes in the dominant circulating virus, or potentially separate epidemics marked by differential social mixing. All three populations were sampled in San Francisco and were at high risk of HCV due to parenteral exposure, but younger patients had significantly lower odds of being infected with GT 1. African-Americans represented $62 \%$ of older IDU, only $1.9 \%$ of younger IDU, and $41.6 \%$ of HIV co-infected patients, but controlling for birth year and other factors, still had

Table 2 Bivariate and multivariate associations between selected demographic characteristics and infection with HCV genotype 1 vs. non-1 (genotypes $2,3,4$ )

\begin{tabular}{|c|c|c|c|c|c|}
\hline & $\%$ with genotype $1 \mathrm{HCV}$ infection & $\begin{array}{l}\text { Odds Ratio } \\
(95 \% \mathrm{Cl})\end{array}$ & $\mathrm{p}$-value & $\begin{array}{l}\text { Adjusted\# Odds } \\
\text { Ratio } \\
(95 \% \mathrm{Cl})\end{array}$ & p-value \\
\hline \multicolumn{6}{|l|}{ Gender } \\
\hline Male & 73.4 & $1.22(0.78,1.90)$ & 0.38 & & \\
\hline Female & 69.3 & & & & \\
\hline \multicolumn{6}{|l|}{ Ethnic Background } \\
\hline Caucasian & 59.2 & 1 & & 1 & \\
\hline African American & 87.1 & $4.65(2.75,7.86)$ & $<0.001$ & $3.37(1.89,5.99)$ & $<0.001$ \\
\hline Latino & 72.0 & $1.77(0.71,4.45)$ & 0.22 & $1.57(0.61,3.98)$ & 0.35 \\
\hline Other & 62.8 & $1.16(0.59,2.30)$ & 0.66 & $1.85(0.59,2.37)$ & 0.63 \\
\hline \multicolumn{6}{|l|}{ Birth Cohort } \\
\hline Born before 1970 & 79.0 & $2.97(1.20,4.59)$ & $<0.001$ & $2.03(1.23,3.34)$ & 0.006 \\
\hline Born 1971 or later & 56.0 & & & 1 & \\
\hline \multicolumn{6}{|l|}{ Study group } \\
\hline UFO & 54.7 & 1 & & ** & \\
\hline UHS & 80.5 & $3.33(2.04,5.45)$ & $<0.001$ & & \\
\hline SCOPE & 76.7 & $2.92(1.68,5.06)$ & $<0.001$ & & \\
\hline
\end{tabular}

** study group was not included in the model as [UFO vs. (UHS and SCOPE)].

\# variables included in the final model were: Ethnic Background and Birth Cohort 
significantly higher odds of subtype $1 \mathrm{HCV}$ infection compared to Caucasian patients. This differential GT distribution by racial group may be due to various factors including temporal, social (mixing), differential access to prevention, and/or possibly genetic explanations. The prevalence of IDU has decreased among younger age groups and among African-American populations in the U.S.[33], and drug injector networks and associated risks may influence the spread of HCV GTs $[34,35]$ as seen with other diseases [36]. Risk groups, in particular IDU compared to non-IDU populations, may have differential access to prevention methods by age, race or other factors that might result in differences in HCV transmission patterns or detection [37-39]. The genetic polymorphism recently associated with treatment and spontaneous clearance of HCV $[14,40]$ occurs with less frequency in African populations, and may account for some of the relative differences seen in HCV GTs prevalence in African Americans and possibly other racial/ethnic groups [19].

To our knowledge no studies have examined GT distribution patterns over several age groups (or by birth cohort) and risk group. In Spain, Serra et al (40), found that GTs varied by risk group: IDU were less likely to be infected with GT $1 \mathrm{~b}$ and more likely to be infected with GTs 1a and 3, compared to transfusion recipients and blood donors, and GT prevalence varied over time in all groups [41]. Our results are also consistent with others who have shown that African-Americans are more likely to be infected with HCV GT $1[18,19]$. Significantly, a very recent report analyzing over 22,000 samples from HCV infected patients at a national reference laboratory in the U.S., found that patients infected with GT 3 were significantly younger $(P<0.0001)$ than those with non-GT 3 (1, 2, or 4). the frequency of $\mathrm{HCV}$ GT 3 ranged from just $4.3 \%$ in subjects over age 70 to $20.6 \%$ in those age 21 to 30 [42]. Our results are consistent with these new findings, and among the first to suggest that the relative prevalence of GT 3 may be increasing as younger groups are more likely to have been recently infected.

This study has some limitations that should be acknowledged. Genotyping was performed by reverse hybridization, and viruses were not sequenced; misclassification could have occurred [43]. Patients may also be infected with multiple GTs, especially IDU who have frequent opportunities for exposure [44], and the assay would have only identified the dominant virus [45]. The groups here are selected from studies of high risk populations in San Francisco, so results may not be generalizable to other risk groups. Finally, two groups (UHS and SCOPE) predominantly represent chronically infected patients, and samples were genotyped only if HCV RNA was present. If there is differential spontaneous clearance in association with HCV GT [26], these results would not reflect the circulating infecting GTs in acutely infected patients, but only those in chronically infected groups.

\section{Conclusions}

IDU are the population most at risk for HCV in the U.S. and younger IDU are most likely to present with more recently acquired infection. Although GT 1 remains the most prevalent GT, especially among older groups, changes in GT distribution coupled with changes in the demography of injection drug use [33] could have important implications for the HCV epidemic. From a public health perspective, these findings might have significant implications for how blood borne virus infections could be controlled on a population level and how they are treated on an individual level.

\section{Acknowledgements}

The following sources of funding supported the investigators and studies participating in this project: U.S. National Institutes for Health (NIH) (R01DA016017-03A1, U19-Al40034-13, K01-DA023365, UL1-RR024131, P30Al27763, R01-DA09532, R01-DA12109, R01-DA13245, R01-DA021550, N01-CO12400); the Substance Abuse and Mental Health Services Administration (H79-TI12103); and the San Francisco Department of Public Health (POHC99001316). Dr. Telles was supported by NIDA Invest Fellowship linked to 2 R01 DA016017-03A1. We also acknowledge the UCSF Liver Center NIH P30 DK026743.

\section{Author details}

${ }^{1}$ Núcleo de Estudos e Pesquisas em Atenção ao Uso de Drogas (NEPAD)Universidade do Estado do Rio de Janeiro (State University of Rio de Janeiro), R Fonseca Teles 121, 4. Andar; 20940-200 Rio de Janeiro, RJ, Brasil. ${ }^{2}$ Department of Epidemiology and Biostatistics, Division of Preventive Medicine and Public Health, Box 1224, 50 Beale Street 1200 University of California San Francisco, San Francisco, CA USA. '3 Department of Medicine, Division of Infectious Disease, San Francisco General Hospital, Box 0811, SFGH Bldg 100 335; University of California San Francisco, San Francisco, CA. 94143 - 0811, USA. ${ }^{4}$ Blood Systems Research Institute, 270 Masonic Avenue, San Francisco, CA 94118, USA. ${ }^{5}$ Department of Medicine, SUNY Downstate College of Medicine, 450 Clarkson Avenue, Box 1240, Brooklyn, NY 11203. USA. ${ }^{6}$ Department of Epidemiology and Biostatistics, Division of Clinical Epidemiology, Box 0560, 185 Berry Street 5700, University of California San Francisco, San Francisco, CA. 94143 - 0560, USA. 7 Department of Medicine, Positive Health Program, San Francisco General Hospital, Box 0874, SFGH Bldg 100 335; University of California San Francisco, San Francisco, CA. 94143 - 0811, USA. ${ }^{8}$ Research Triangle Institute (RTI), San Francisco, CA USA. ${ }^{9}$ Department of Laboratory Medicine, Box 0134, University of California San Francisco San Francisco, CA. 94143 - 0134 USA.

\section{Authors' contributions}

All authors made substantive intellectual contributions to the study, including to conception and design, or acquisition of data, or analysis and interpretation of data, and drafting or revising the manuscript. All authors read and approved the final manuscript. PTD participated in the study conception, data analysis and drafting of the manuscript. JAH participated in study design, acquisition and analysis of data, and manuscript revisions. ED, $B R E, J M, S T, P L, J E, A K, S D$ and MB participated in study design, data acquisition, and drafting the manuscript. KP conceived of the study, participated in data collection and analyses, and the drafting and finalizing of the manuscript.

\section{Competing interests}

The authors declare that they have no competing interests. 
Received: 27 January 2011 Accepted: 2 August 2011

Published: 2 August 2011

\section{References}

1. Simmonds P, Bukh J, Combet C, Deleage G, Enomoto N, Feinstone S, Halfon P, Inchauspe G, Kuiken C, Maertens G, Mizokami M, Murphy DG, Okamoto H, Pawlotsky JM, Penin F, Sablon E, Shin IT, Stuyver LJ, Thiel HJ, Viazov S, Weiner AJ, Widell A: Consensus proposals for a unified system of nomenclature of hepatitis C virus genotypes. Hepatology 2005, 42(4):962-973.

2. Fried MW, Shiffman ML, Reddy KR, Smith C, Marinos G, Goncales FL, Haussinger D, Diago M, Carosi G, Dhumeaux D, Craxi A, Lin A, Hoffman J, Yu J: Peginterferon alfa-2a plus ribavirin for chronic hepatitis $C$ virus infection. N Engl J Med 2002, 347(13):975-982.

3. Manns MP, McHutchison JG, Gordon SC, Rustgi VK, Shiffman M, Reindollar R, Goodman ZD, Koury K, Ling M, Albrecht JK: Peginterferon alfa- $2 \mathrm{~b}$ plus ribavirin compared with interferon alfa- $2 \mathrm{~b}$ plus ribavirin for initial treatment of chronic hepatitis C: a randomised trial. Lancet 2001, 358(9286):958-965.

4. Muir AJ, Bornstein JD, Killenberg PG: Peginterferon alfa-2b and ribavirin for the treatment of chronic hepatitis $\mathrm{C}$ in blacks and non-Hispanic whites. N Engl J Med 2004, 350(22):2265-2271.

5. McHutchison JG, Gordon SC, Schiff ER, Shiffman ML, Lee WM, Rustgi VK, Goodman ZD, Ling MH, Cort S, Albrecht JK: Interferon alfa-2b alone or in combination with ribavirin as initial treatment for chronic hepatitis $C$. Hepatitis Interventional Therapy Group [see comments]. N Engl I Med 1998, 339(21):1485-1492.

6. Tobler LH, Bahrami SH, Kaidarova Z, Pitina L, Winkelman VK, Vanderpool SK, Guiltinan AM, Cooper S, Busch MP, Murphy EL: A case-control study of factors associated with resolution of hepatitis $\mathrm{C}$ viremia in former blood donors (CME). Transfusion 50(7):1513-1523.

7. Thomas DL, Astemborski J, Rai RM, Anania FA, Schaeffer M, galai N, Nolt K, Nelson KE, Strathdee SA, Johnson L, Laeyendecker O, Boitnott J, Wilson LE, Vlahov D: The natural history of hepatitis $\mathrm{C}$ virus infection. Journal of the American Medical Association 2000, 284(4):450-456.

8. Schito ML, D'Souza MP, Owen SM, Busch MP: Challenges for rapid molecular HIV diagnostics. J Infect Dis 201(Suppl 1):S1-6.

9. Moucari R, Asselah T, Cazals-Hatem D, Voitot H, Boyer N, Ripault MP, Sobesky R, Martinot-Peignoux M, Maylin S, Nicolas-Chanoine MH, Paradis V, Vidaud $M$, Valla D, Bedossa P, Marcellin P: Insulin resistance in chronic hepatitis C: association with genotypes 1 and 4, serum HCV RNA level, and liver fibrosis. Gastroenterology 2008, 134(2):416-423.

10. Yoo TW, Donfield S, Lail A, Lynn HS, Daar ES: Effect of hepatitis C virus (HCV) genotype on HCV and HIV-1 disease. J Infect Dis 2005, 191(1):4-10

11. Farci P, Purcell RH: Clinical significance of hepatitis $C$ virus genotypes and quasispecies. Semin Liver Dis 2000, 20(1):103-126.

12. Hepburn MJ, Hepburn LM, Cantu NS, Lapeer MG, Lawitz EJ: Differences in treatment outcome for hepatitis C among ethnic groups. Am J Med 2004, 117(3):163-168.

13. Kinzie JL, Naylor PH, Nathani MG, Peleman RR, Ehrinpreis MN, Lybik M, Turner JR, Janisse JJ, Massanari M, Mutchnick MG: African Americans with genotype 1 treated with interferon for chronic hepatitis $C$ have a lower end of treatment response than Caucasians. J Viral Hepat 2001, 8(4):264-269.

14. Ge D, Fellay J, Thompson AJ, Simon JS, Shianna KV, Urban TJ, Heinzen EL, Qiu P, Bertelsen AH, Muir AJ, Sulkowski M, McHutchison JG, Goldstein DB: Genetic variation in IL28B predicts hepatitis C treatment-induced viral clearance. Nature 2009, 461(7262):399-401.

15. Thomas DL, Thio CL, Martin MP, Qi Y, Ge D, O'Huigin C, Kidd J, Kidd K, Khakoo SI, Alexander G, Goedert JJ, Kirk GD, Donfield SM, Rosen HR, Tobler LH, Busch MP, McHutchison JG, Goldstein DB, Carrington M: Genetic variation in IL28B and spontaneous clearance of hepatitis C virus. Nature 2009, 461(7265):798-801.

16. Strickland GT, El-Kamary SS, Klenerman P, Nicosia A: Hepatitis C vaccine: supply and demand. Lancet Infect Dis 2008, 8(6):379-386.

17. Alter MJ: Hepatitis C virus infection in the United States. J Hepatol 1999, 31(Suppl 1):88-91.

18. Blatt LM, Mutchnick MG, Tong MJ, Klion FM, Lebovics E, Freilich B, Bach N, Smith C, Herrera J, Tobias H, Conrad A, Schmid P, McHutchison JG: Assessment of hepatitis C virus RNA and genotype from 6807 patients with chronic hepatitis C in the United States. J Viral Hepat 2000, 7(3):196-202.

19. Nainan OV, Alter MJ, Kruszon-Moran D, Gao FX, Xia G, McQuillan G, Margolis HS: Hepatitis C virus genotypes and viral concentrations in participants of a general population survey in the United States. Gastroenterology 2006, 131(2):478-484

20. Payan C, Roudot-Thoraval F, Marcellin P, Bled N, Duverlie G, FouchardHubert I, Trimoulet P, Couzigou P, Cointe D, Chaput C, Henquell C, Abergel A, Pawlotsky JM, Hezode C, Coude M, Blanchi A, Alain S, LoustaudRatti V, Chevallier P, Trepo C, Gerolami V, Portal I, Halfon P, Bourliere M, Bogard M, Plouvier E, Laffont C, Agius G, Silvain C, Brodard V, et al: Changing of hepatitis $C$ virus genotype patterns in France at the beginning of the third millenium: The GEMHEP GenoCII Study. J Viral Hepat 2005, 12(4):405-413.

21. Chlabicz S, Flisiak R, Kowalczuk O, Grzeszczuk A, Pytel-Krolczuk B, Prokopowicz D, Chyczewski L: Changing HCV genotypes distribution in Poland-relation to source and time of infection. J Clin Virol 2008, 42(2):156-159.

22. Bourliere M, Barberin JM, Rotily M, Guagliardo V, Portal I, Lecomte L, Benali S, Boustiere C, Perrier H, Jullien M, Lambot G, Loyer R, LeBars O, Daniel R, Khiri H, Halfon P: Epidemiological changes in hepatitis C virus genotypes in France: evidence in intravenous drug users. J Viral Hepat 2002, 9(1):62-70

23. Katsoulidou A, Sypsa V, Tassopoulos NC, Boletis J, Karafoulidou A, Ketikoglou I, Tsantoulas D, Vafiadi I, Hatzis G, Skoutelis A, Akriviadis E, Vasiliadis T, Kitis G, Magiorkinis G, Hatzakis A: Molecular epidemiology of hepatitis $\mathrm{C}$ virus (HCV) in Greece: temporal trends in HCV genotypespecific incidence and molecular characterization of genotype 4 isolates. J Viral Hepat 2006, 13(1):19-27.

24. Schroter M, Zollner B, Schafer P, Reimer A, Muller M, Laufs R, Feucht HH: Epidemiological dynamics of hepatitis $C$ virus among 747 German individuals: new subtypes on the advance. J Clin Microbiol 2002, 40(5):1866-1868

25. Lorvick J, Kral AH, Seal K, Gee L, Edlin BR: Prevalence and duration of hepatitis C among injection drug users in San Francisco, Calif. Am J Public Health 2001, 91(1):46-47.

26. Page K, Hahn JA, Evans J, Shiboski S, Lum P, Delwart E, Tobler L, Andrews W, Avanesyan L, Cooper S, Busch MP: Acute hepatitis C virus infection in young adult injection drug users: a prospective study of incident infection, resolution, and reinfection. J Infect Dis 2009, 200(8):1216-1226.

27. Hunt PW, Brenchley J, Sinclair E, MCCune JM, Roland M, Page-Shafer K, Hsue P, Emu B, Krone M, Lampiris H, Douek D, Martin JN, Deeks SG: Relationship between T Cell Activation and CD4(+) T Cell Count in HIVSeropositive Individuals with Undetectable Plasma HIV RNA Levels in the Absence of Therapy. J Infect Dis 2008, 197(1):126-133.

28. Gish RG, Qian K, Brooks L, Leung J, Xu Y, Pike I, Lau JY: Characterization of anti-hepatitis $C$ virus-positive sera not genotyped by restriction fragment length polymorphism or serology. J Gastroenterol Hepatol 1999, 14(4):339-344

29. Simmonds P, Mellor J, Craxi A, Sanchez-Tapias JM, Alberti A, Prieto J, Colombo M, Rumi MG, Lo lacano O, Ampurdanes-Mingall S, FornsBernhardt X, Chemello L, Civeira MP, Frost C, Dusheiko G: Epidemiological, clinical and therapeutic associations of hepatitis $\mathrm{C}$ types in western European patients. J Hepatol 1996, 24(5):517-524.

30. Dal Molin G, Ansaldi F, Biagi C, D'Agaro P, Comar M, Croce L, Tiribelli C, Campello C: Changing molecular epidemiology of hepatitis $C$ virus infection in Northeast Italy. J Med Virol 2002, 68(3):352-356.

31. Mathei C, Wollants E, Verbeeck J, Van Ranst M, Robaeys G, Van Damme P, Buntinx F: Molecular epidemiology of hepatitis $C$ among drug users in Flanders, Belgium: association of genotype with clinical parameters and with sex- and drug-related risk behaviours. Eur I Clin Microbiol Infect Dis 2005, 24(8):514-522.

32. van Asten L, Verhaest I, Lamzira S, Hernandez-Aguado I, Zangerle R, Boufassa F, Rezza G, Broers B, Robertson JR, Brettle RP, McMenamin J, Prins M, Cochrane A, Simmonds P, Coutinho RA, Bruisten S: Spread of hepatitis $C$ virus among European injection drug users infected with HIV: a phylogenetic analysis. J Infect Dis 2004, 189(2):292-302.

33. Armstrong GL: Injection drug users in the United States, 1979-2002: an aging population. Arch Intern Med 2007, 167(2):166-173. 
34. Bluthenthal RN, Do DP, Finch B, Martinez A, Edlin BR, Kral AH: Community characteristics associated with HIV risk among injection drug users in the San Francisco Bay Area: a multilevel analysis. J Urban Health 2007, 84(5):653-666.

35. Johnson RA, Gerstein DR, Pach A, Cerbone FG, Brown J: HIV risk behaviors in African-American drug injector networks: implications of injectionpartner mixing and partnership characteristics. Addiction 2002, 97(8):1011-1024.

36. Friedman SR, Lieb S, Tempalski B, Cooper H, Keem M, Friedman R, Flom PL: HIV among injection drug users in large US metropolitan areas, 1998. J Urban Health 2005, 82(3):434-445.

37. Cooper HL, Bossak BH, Tempalski B, Friedman SR, Des Jarlais DC: Temporal trends in spatial access to pharmacies that sell over-the-counter syringes in New York City health districts: relationship to local racial/ ethnic composition and need. J Urban Health 2009, 86(6):929-945.

38. Heinzerling KG, Kral AH, Flynn NM, Anderson RL, Scott A, Gilbert ML, Asch SM, Bluthenthal RN: Human immunodeficiency virus and hepatitis $C$ virus testing services at syringe exchange programs: availability and outcomes. J Subst Abuse Treat 2007, 32(4):423-429.

39. Stopka TJ, Garfein RS, Ross A, Truax SR: Increasing syringe access and HIV prevention in California: findings from a survey of local health jurisdiction key personnel. J Urban Health 2007, 84(1):116-125.

40. Thomas DL, Thio CL, Martin MP, Qi Y, Ge D, O'Huigin C, Kidd J, Kidd K, Khakoo SI, Alexander G, Goedert JJ, Kirk GD, Donfield SM, Rosen HR, Tobler LH, Busch MP, McHutchison JG, Goldstein DB, Carrington M: Genetic variation in IL28B and spontaneous clearance of hepatitis C virus. Nature 2009.

41. Serra MA, Rodriguez F, del Olmo JA, Escudero A, Rodrigo JM: Influence of age and date of infection on distribution of hepatitis $C$ virus genotypes and fibrosis stage. J Viral Hepat 2003, 10(3):183-188.

42. Germer JJ, Mandrekar JN, Bendel JL, Mitchell PS, Yao JD: Hepatitis C Virus Genotypes in Clinical Specimens Tested at a National Reference Testing Laboratory in the United States. J Clin Microbiol 2011.

43. Nadarajah R, Khan GY, Miller SA, Brooks GF: Evaluation of a newgeneration line-probe assay that detects $5^{\prime}$ untranslated and core regions to genotype and subtype hepatitis C virus. Am J Clin Pathol 2007, 128(2):300-304.

44. Herring BL, Page-Shafer K, Tobler LH, Delwart EL: Frequent hepatitis C virus superinfection in injection drug users. J Infect Dis 2004, 190(8):1396-1403.

45. Schroter M, Feucht HH, Zollner B, Schafer P, Laufs R: Multiple infections with different HCV genotypes: prevalence and clinical impact. J Clin Virol 2003, 27(2):200-204.

Pre-publication history

The pre-publication history for this paper can be accessed here: http://www.biomedcentral.com/1471-2334/11/208/prepub

doi:10.1186/1471-2334-11-208

Cite this article as: Dias et al: Temporal changes in HCV genotype distribution in three different high risk populations in San Francisco, California. BMC Infectious Diseases 2011 11:208.

\section{Submit your next manuscript to BioMed Central and take full advantage of:}

- Convenient online submission

- Thorough peer review

- No space constraints or color figure charges

- Immediate publication on acceptance

- Inclusion in PubMed, CAS, Scopus and Google Scholar

- Research which is freely available for redistribution

Submit your manuscript at www.biomedcentral.com/submit
Biomed Central 